\title{
On Determinism and Freedom
}


Other books by Ted Honderich published by Edinburgh University Press After the Terror (2002; paperback 2003)

On Political Means and Social Ends (2003)

On Consciousness (2004) 


\section{On Determinism and Freedom}

Ted Honderich

Edinburgh University Press 
(C) Ted Honderich, 2005

Edinburgh University Press Ltd 22 George Square, Edinburgh

Typeset in 11/13 Palatino and Futura by TechBooks India, and printed and bound in Great Britain by

The Cromwell Press, Trowbridge, Wilts

A CIP record for this book is available from the British Library

ISBN 0748618414 (hardback)

The right of Ted Honderich to be identified as author of this work has been asserted in accordance with the Copyright, Designs and Patents Act 1988. 